\title{
EKSPANSI ABSES BUKAL SINISTRA KEARAH COLLI DAN THORAKS DISERTAI
} PERFORASI GASTER

Yayun Siti Rochmah*

Keywords:
Abcess, NSAID, Gaster
perforation

\begin{abstract}
Background: Abscess is infection caused of anerob bacteria. Maxillofacial abcess aetiology was oral focus infection like dental gangren. Unproportional treatment could make complication that makes sistemic condition patient worst, gaster perforation. Objective : to present treatment bucal abscess case that expanding to colli, thoraks and complication based on mistherapy about NSAID with gaster perforation.
\end{abstract}

Case and management: A 59 years old man with chief complain colli abscess and suspect gaster perforation with diffuse abdominal pain and distension gaster since three days. Intraoral inspection was multipel dental gangren. Ultrasonography showed gaster perforation. Incicion drainase was done and eradication oral focus infection with repair gaster perforation under general anaesthesia prosedure. Medication treatment with ceftriaxone injection $2 x$ $1 \mathrm{gram}$, and paracetamol infus $3 \times 500 \mathrm{mg}$. Bacteria kulture was negatif and hospitalization patient until 1 week.

Discussion: Gold standart abscess therapy is incision drainase, but there were clinician not aware abiut that and choosed konservative treatment with antibiotic and analgesic, so that less maximal theraphy. Complication NSAID analgesic was gaster iritation, so unproportional drug treatment can lead gaster ulceration or perforation.

Conclusion: It is important and consider drug choise for abscess treatment to avoid worst complication development.

\section{PENDAHULUAN}

Abses merupakan keluhan pasien yang sering kita temui dalam kedokteran gigi. Abses daerah maksilofasial lebih banyak disebabkan akibat infeksi gigi. Penanganan yang paling sering dilakukan oleh dokter gigi adalah pemberian antibiotika dan antinyeri. Penanganan ideal abses berupa insisi drainase justru jarang dilakukan dikarenakan minimnya fasilitas di faskes tingkat pertama, sehingga penanganan kurang maksimal. Pemberian analgesik merupakan pilihan paling mudah untuk penanganan rasa nyeri pasien abses. Pemilihan jenis analgesik yang mampu bekerja cepat dan bertahan lama merupakan yang paling sering diberikan oleh dokter gigi, tanpa memperhitungkan efek samping penggunaan dalam waktu lama. Abses yang didukung dengan kondisi oral hygiene dan kondisi sistemik jelek akan mempercepat penyebaran abses ke organ sesuai arah grativasi bumi. ${ }^{2}$ Abses bukal yang tidak ditangani dengan baik, akan menyebar kedaerah leher (colli) dan thoraks. Pemakainan analgesik jenis NSAID dalam jangka lama dapat memberikan efek perforasi gaster.

\section{KASUS DAN PENANGANAN}

Pasien laki-laki berusia 59 tahun datang ke RSI Sultan Agung Semarang rujukan dari RS daerah dengan keluhan perut kurang nyaman disertai bengkak pipi kiri menyebar sampai

\footnotetext{
${ }^{* * *}$ Departemen Bedah Mulut dan Maksilofasial Fakultas Kedokteran Gigi Universitas Islam Sultan Agung Korespondensi : yayun@unissula.ac.id
} 
leher dan dada pasien disertai nyeri perut dan kembung yang dirasakan sejak 3 hari yang lalu. Riwayat sebelumnya pasien terdapat bengkak pipi kiri dan nyeri serta telah diobati oleh dokter gigi setempat dengan antibiotika dan anti nyeri NSAID, tetapi keluhan tidak reda bahkan semakin menyebar dengan cepat sampai ke leher dan dada. Pasien dirawat inap di RS setempat dengan terapi antibiotika dan anti nyeri injeksi jenis NSAID selama beberapa hari sampai kemudian muncul keluhan perut yang kurang nyaman disertai sesak dan dirujuk ke Semarang.

Pemeriksaan obyektif secara umum pasien tampak lemah dan sesak. Pemeriksaan ekstraoral tampak pembengkakan dan berwarna kemerahan di bukal sinistra, colli dan thorak pada sisi yang sama. Pemeriksaan palpasi abdomen didapatkan nyeri tekan pada seluruh kuadran abdomen. Defans muskular(+). Pemeriksaan intraoral tampak gigi-gigi multipel karies dan kalkulus disertai ginggiva kemerahan. (gambar 1 dan 2).

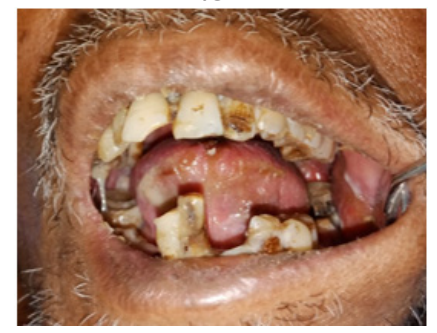

Gambar 1. Gambaran Intraoral

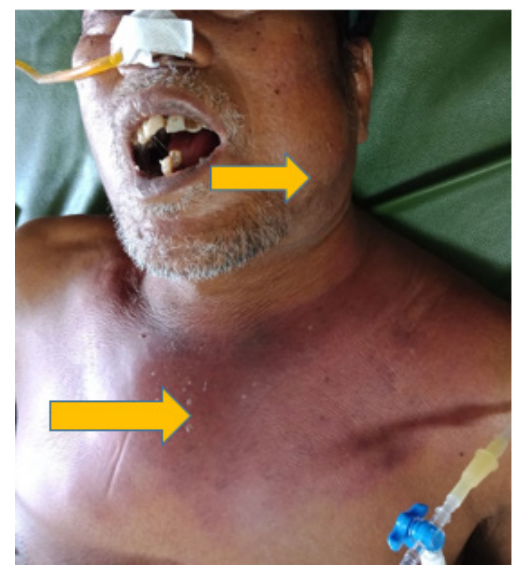

Gambar 2. Gambaran ekstraoral
Pemeriksaan penunjang yang dilakukan :

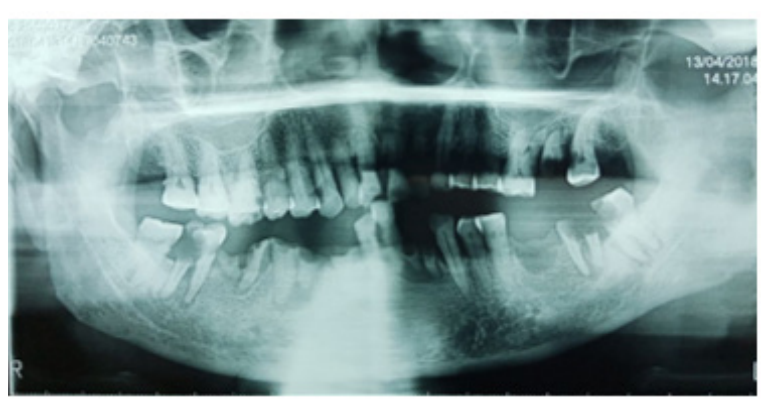

Gambar (3) Foto panoramik

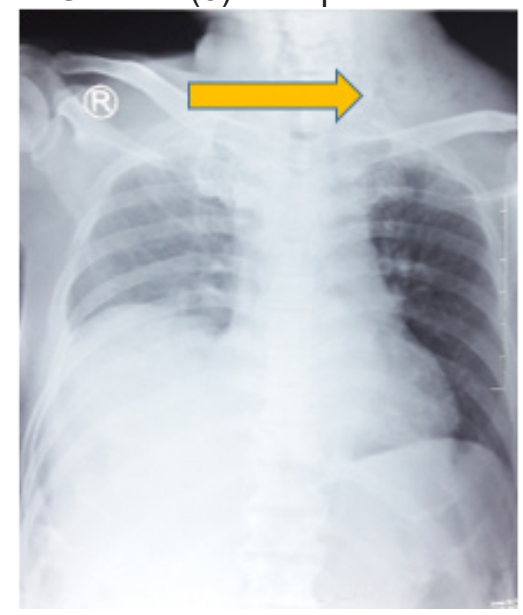

Gambar (4) Foto thoraks

Foto panoramik tampak gambaran gigi-gigi sisa akar dengan radiolusen pada periapikalnya (Gambar 3), foto thorak tampak gambaran groundglass pada subklavikula sinistra yang sudah mendesak trakea (Gambar 4), pemeriksaan USG tampak kesan cairan bebas intraabdomen. Pemeriksaan labroratorium darah : Hb : 11,7 g/dL, Leukosit : 20.7 ribu/uL

Penatalaksanaan : dilakukan insisi drainase regio colii dan thoraks (Gambar 5) dan repair perforasi gaster (Gambar 6) serta eradikasi sumber infeksi dengan general anestesi oleh spesialis bedah mulut dan bedah umum. Debridement dilakukan untuk membuang jaringan nekrotik serta pemasangan drain kasa. Terapi medikamentosa pasca operasi dengan pemberian antibiotika, analgesik, obat kumur dan roborontia untuk meningkatkan imunitas pasien. Kulkur pus dan rawat luka dilakukan dengan hasil negatif. 


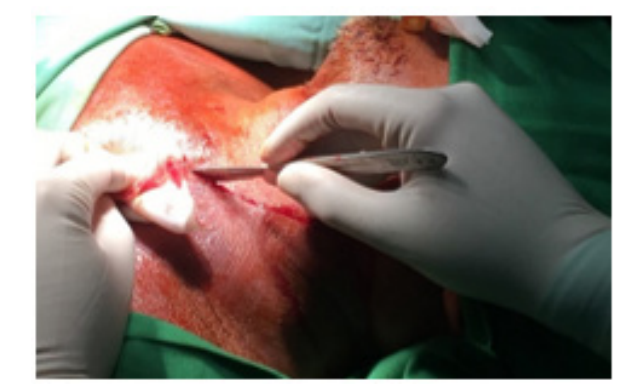

Gambar (5) Insisi drainase daerah thoraks

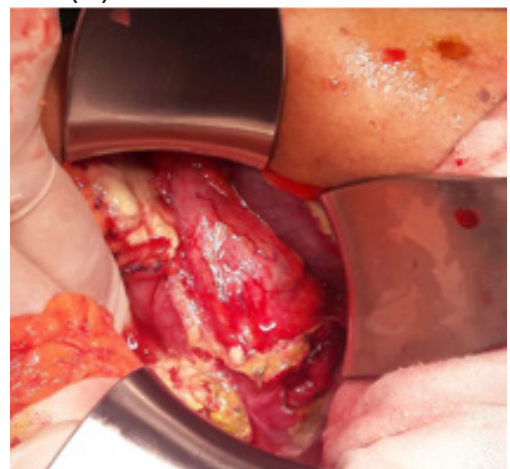

Gambar (6) Repair Perforasi gaster

\section{DISKUSI}

Abses regio maksilofasial sering disebabkan karena infeksi gigi dan jaringan penyangganya. Penyebaran abses sangat dipengaruhi oleh beberapa faktor, salah satunya kondisi fisik pasien yang berpengaruh semakin cepat proses penyebaran abses. Daya tahan tubuh (imunitas) yang menurun menyebabkan penyebaran infeksi semakin cepat dan akan memperburuk keadaan pasien. ${ }^{3}$ Penyebaran infeksi rongga mulut dapat menyebar kedaerah sekitarnya seperti daerah leher (colli) bahkan dapat mencapai bagian yang jauh seperti thoraks dan mediastinum. Penyebaran infeksi dapat melalui bakterimia atau perkontinuatum melalui struktur anatomis disekitarnya ${ }^{4}$ disertai toksimia akibat bakteri patogen. Penyebaran infeksi akan diperparah dengan respon autoimun dan diseminasi atau absesifikasi melalui jalur anatomi. Tiga rute potensial untuk penyebaran fokus infeksi intraoral yaitu retrofaringeal, perivaskular dan pretrakheal. ${ }^{4}$ Arah penyebaran pus sesuai dengan arah gravitasi bumi, sehingga abses rongga mulut dapat menyebar kearah leher, thorak dan mediastinum. Apabila hal ini terjadi, maka prognosa akan jelek. Pada kasus ini dimulai dengan abses bukal sinistra yang dengan cepat menyebar daerah colli sinistra dan turun kearah thoraks sinistra, tetapi daerah mediastinum masih aman.Penyebaran abses yang cepat pada pasien ini disebabkan karena kondisi intraoral yang jelak dan penanganan abses yang kurang tepat.

Penanganan abses yang ideal berupa pelaksanaan insisi drainase untuk mengurangi kompresi dan mengeluarkan produk infeksi. ${ }^{4}$ Drainase yang sempurna akan mempercepat proses penyembuhan dengan melakukan diseksi pada area yang diduga sebagai kantong pus. Irigasi yang adekuat dan pemasangan drain menyempurnakan proses drainase. $^{5}$ Setelah dilakukan insisi drainase, dilakukan eradikasi sumber infeksi, apabila sumbernya dari infeksi gigi gangren, maka gigi harus segera dilakukan pencabutan. ${ }^{6}$

Pemberian antibiotika dan analgesik sebagai pendukung. Tetapi sering dalam praktek sehari-hari, penanganan abses kurang maksimal yaitu dengan pemberian antibiotika dan analgesik adalah yang utama tanpa insisi drainase. Pemberian analgesik untuk menghilangkan simptom nyeri merupakan pilihan terapi yang paling mudah. Tetapi pemberian analgesik yang kurang sesuai dengan aturan dapat mnegakibatkan komplikasi yang memperparah keadaan pasien. Terutama untuk analgesik golongan NSAID (Non steroid Inflamatory Drug) yang mempunyai efek samping berupa ulser gaster. Pada pasien ini, untuk menghilangkan nyeri diberikan analgesik NSAID dalam jangka waktu lama, dimana pasien ada riwayat 
gastritis yang tidak terdeteksi oleh dokter yang merawat. Prevalensi kejadian ulser gaster 15$30 \%$, diantara prevalensi tersebut sekitar $2 \%$ terjadi didaerah duodenum. Lama pemakaian NSAID yang dapat menimbulkan ulser gaster dengan pemakaian selama 1 bulan (1\%) dan 3-6 bulan $(4 \%){ }^{7}$

Empat jalur mekanisme NSAID dapat menyebabkan kerusakan gastrointertinal yaitu (1) Topical injury yaitu peran NSAID dalam merusak epitel gaster dengan akumulasi intraseluler obat yang terionisasi, (2) Hambatan sintesa prostaglandin yaitu sebagaimana kita ketahui NSAID bekerja menghambat enzim sikooksigenasi yang berperan merubah asam arakhidonat menjadi prostaglandin, sedangkan prostaglandin berfungsi menjaga pertahanan mukosa gastrointestinal, sehingga NSAID dapat menimbulkan perlukaan mukosa, erose dan ulser, (3) Nitric oxid, yaitu peran nitric oxid (NO) meningkatkan aliran darah mukosa gastrointestinal, menstimulasi sekresi mukus dan menghambat masuknya netrofil. NO merupakan pelepasan produk NSAID, (4) Neutrophil-mediated injury yaitu masuknya netrofil kedalam endotelium kerusakan mikrosirkulasi mukosa gaster dengan melepaskan radikal bebas, protein dan menghambat aliran darah kapiler. NSAID diperkirakan menstimulasi masuknya netrofil dengan meningkatkan pengaturan adesi molekul. ${ }^{8}$

Penanganan pada kasus ini dilakukan insisi drainase regio colli dan thoraks sampai pus keluar semua, dilakukan irigasi dan pemasangan kasa drain yang dipetahankan sampai 3 hari dengan perawatan ganti kasa drian setiap hari. Pemberian antibiotika ceftriaxone $2 \times 1$ gram untuk memaksimalkan terapi dan analgesik yang aman bagi lambung yaitu parasetamol infus $3 \times 500 \mathrm{mg}$. Selama proses penyembuhan post repair perforasi gaster, pasien diet cair via NGT (Naso gastric tube) untuk menghindari mikro taruma pada mukosa lambung. Setelah dilakukan perawatan secara intensif selama satu minggu kondisi pasien semakin membaik dan diperkanankan pulang untuk kontrol satu minggu kemudian.

\section{KESIMPULAN}

Penanganan abses yang benar dan adekuat serta mempertimbangkan kondisi sistemik pasien, akan tercapai hasil yang baik.

\section{DAFTAR PUSTAKA}

1. Arias Bartolomé, Contreras Marian, Acosta Antonio, Delgado Francisco, Bemudo Lucas, Antonio Valiente, Multiple odontogenic abscesses. Thoracic and abdomino-perineal extensión in an immuno competent patient, Med Oral Patol Oral Cir Bucal,2011;16 (6):e772-5

2. UJ Moore, Principle of Oral and Maxillofacial Surgery, 5 ed Blackwell Science, United Kingdom, 2001. p.156.

3. ArunKumar K.V. dan Deepa Dhruvakumar, Migratory and misleading abscess of oro-facial region, J Indian Soc Periodontol. 2015 Jul-Aug; 19(4): 470-473.

4. Ariawan $\mathrm{YK}$ dan Surarso B, Penatalaksanaan abses retrofaring dengan komplikasi mediastinitis dan empiema toraks, Jurnal THT-KL.Vol. 5, No.1, Januari - April 2012, hlm. 14 - 27.

5. James Walters, Noeleen Foley, Matthew Molyneux, Pus in the thorax: management of empyema and lung abscess, Continuing Education in Anaesthesia, Critical Care \& Pain ,2011,Vol.11 No. 6.

6. Kubsad Veerabhadrappa A. and Dhruvakumar D. Migratory and misleading abscess of oro-facial region, J Indian Soc Periodontol. 2015 Jul-Aug; 19(4): 470-473.

7. Valerie Vella, Drug-induced peptic ulcer disease, Journal of the Malta College of Pharmacy Practice, 2005,Issue 10 Summer

8. Edgar NG, Luis CV, Ricardo SM, et al, Drug related colonic perforation : Case report, Cirugia y Cirujanos, 2016, 84(1):65-8. 